\title{
Graduate Enhancement Program in Southeast Asia
}

\author{
Ismail Suardi Wekke \\ Southeast Asia Academic Mobility \\ Email: $\underline{\text { admin@ @seaam.net }}$
}

\section{Surahman Amin}

Pascasarjana Sekolah Tinggi Agama Islam Negeri (STAIN) Sorong

Email: surahmanamin@stainsorong.ac.id

\begin{abstract}
ABSTRAK
Kolaborasi dan sinergi kelembagaan menjadi keperluan, termasuk di tingkat pascasarjana. Olehnya, jaringan kerjasama antara pengelola pascasarjana diperlukan untuk diwujudkan. Untuk sampai pada tujuan itu, perlu kebersamaan dan juga tata kelola bersama sehingga dapat saling membantu. Kertas kerja ini adalah rancangan kegiatan Graduate Student Symposium sebagai Graduate Enhancement Program in Southeast Asia yang akan dilaksanakan di Malaysia, Thailand, dan Singapura, pada bulan September 2020.
\end{abstract}

Kata Kunci: pascasarjana; pendidikan tinggi; pembelajaran kelas.

\section{Pendahuluan}

Ketika itu, 2016, Direktur Pascasarjana Institut Agama Islam Negeri (IAIN) Manado, Dr. KH. Rivai Bolotio, bersama-sama dengan dosen pascasarjana Sekolah Tinggi Agama Islam Negeri (STAIN) Sorong, Dr. Ismail Suardi Wekke, menyertai acara kunjungan program magister Jurusan Hubungan Internasional Universitas Airlangga ke Malaysia dan Thailand, dikoordinir Dr. Baiq Wardani. Diskusi dalam perjalanan kemudian menjadi awal untuk melaksanakan pertemuan di Manado sekaligus melaksanakan International Postgraduate Research Conference (IPRC) untuk kali pertama. Hasil IPRC menerbitkan buku (Rajafi, 2018).

Dalam IPRC itu pulalah bertemu 16 perguruan tinggi dari Malaysia, dan Thailand. Dengan tuan rumah Institut Agama Islam Negeri (IAIN) Manado. Pertemuan yang bertempat di gedung pascasarjana IAIN Manado menyepakati terbentuknya SEAAM. Selanjutnya berkembang dengan kegiatan-kegiatan dengan fokus pada pelayanan keperluan mahasiswa pascasarjana.

Bersama-sama dengan Pascasarjana Sekolah Tinggi Agama Islam Negeri (STAIN) Sorong sejak awal turut berpartisipasi dalam pelaksanaan kegiatan-kegiatan SEAAM. Maka, untuk 2020 diprakarsai Academic Enhancement Program in Southeast Asia. Kegiatan akan dilaksanakan dengan partisipasi utama berasal dari pascasarjana, baik dosen maupun mahasiswa. Kegiatan akan dilaksanakan di tiga negara yaitu Malaysia, Thailand, dan Singapura. Pelaksanaan AEP, sekaligus akan memberikan kesempatan bagi mahasiswa dalam meningkatkan kualitas 
tesis yang sementara ditulis. Ini akan menjadi teknik dalam pengembangan pendidikan tinggi Papua (Wekke, Kahar, \& Amri, 2018).

\section{Pertanyaan Terkait SEAAM}

Kewujudan SEAAM, sebagai jaringan mendapatkan tanggapan. Pertanyaan yang terkait SEAAM dikemukakan berkali-kali, antara lain:

Pertanyaan Pertama: Apa itu SEAAM?

Southeast Asia Academic Mobility (SEAAM) jaringan persahabatan dosen di Asia Tenggara. Dibentuk tanggal 12 November 2016 di IAIN Manado, ketika itu menjabat rektor Prof. Dr. Hj. Rukmina Gonibala, pada saat International Postgraduate Research Conference (IPRC) pertama kali dengan ketua panitia, Dr. KH. Ahmad Rajafi, sekarang beliau Wakil Rektor Bidang Akademik IAIN Manado. Pelaksanaan IPRC Saat itu juga pertemuan mendiskusikan untuk meminta kesediaan Dr. Suyatno Ladiqi sebagai Sekretaris Jenderal SEAAM. Scientific Committee awal yang diminta sebagai Advisory Board Prof. Dr. Afandi Salleh (Universiti Sultan Zainal Abidin, Malaysia) dan Prof. Dr. Sukree Langputeh (Fatoni University, Thailand). Selanjutnya setelah IPRC (2016, Manado), dilaksanakan kembali IPRC (2018, Manado), dan IPRC (Padang, 2019). Direncanakan untuk 2019, IPRC akan dilaksanakan di Pahang, Malaysia.

Pertanyaan Kedua: Adakah kartu keanggotaan?

Tidak ada. SEAAM hanya jaringan persahabatan. Bukan keanggotaan. Setiap orang dapat bergabung dalam acara yang dilaksanakan dengan pola kolaborasi dan sinergi antar perguruan tinggi.

Pertanyaan Ketiga: Bagaimana caranya bergabung?

Setiap orang, baik mahasiswa maupun dosen dapat bergabung sebagai peserta atau panitia dalam kegiatan-kegiatan yang dilaksanakan bersama SEAAM. Jika anda punya ide atau usulan untuk dilaksanakan bersama dengan SEAAM silahkan dikirim melalui email: admin@seaam.net.

Pertanyaan Keempat: Bagaimana pembiayaan?

Scientific Committee tidak dibayar, bekerja secara volunteer. Setiap orang juga tidak dibebani ada iuran. Skema pembiayaan kegiatan merupakan kontribusi bersama antara SC dan juga peserta dalam setiap kegiatan. 
Pertanyaan Kelima: Apa saja kegiatan SEAAM?

Secara berkala dilaksanakan IPRC (International Postgraduate Research Conference). Juga International Colloquium on Environmental Education, Mobility Student, Visiting Lecture, SEA-AFSID. Kolaborasi simposium dilaksanakan bersama Universitas Negeri Semarang. Demikian pula penerbitan buku. Sementara ini bersama dengan STISIP Amal Ilmiah YAPIS Wamena disiapkan penerbitan jurnal, JIRAN: Journal of Southeast Asia Studies dengan tautan yang beralamat: https://journal.seaam.net/index.php/jiran. Informasi selengkapnya dapat dilihat di www.seaam.net.

Pertanyaan Keenam: Dimana sekretariat SEAAM?

SEAAM bersekretariat di STISIP Amal Ilmiah YAPIS Wamena, Papua, Indonesia. Kenapa di Papua? Untuk menjadi prakarsa bahwa Papua diikhtiarkan bagi mendapatkan daya sanding dengan perguruan tinggi di Asia Tenggara. Dengan berada di Papua, ikhtiar ini akan menjadi permulaan sehingga dapat memberikan penguatan kepada perguruan tinggi Papua bahwa mereka tidak tidak, tidak terkebelakang, dan tidak sepi dari perhatian mitra dari seluruh Asia Tenggara.

\section{Tujuan Program}

Selama mengikuti Graduate Enhancement Program in Southeast Asia, baik mahasiswa maupun dosen memiliki kesempatan untuk bersama-sama belajar. Mahasiswa akan memiliki peluang menyajikan proposal tesis, maupun work in progress tesis yang sementara ditulis. Sekaligus dengan berdialog di perpustakaan, mahasiswa akan meningkatkan mutu tesisnya dmana dapat mengakses bahan kepustakaan yang tersedia di masing-masing kampus. Perpustakaan UniSZA meluaskan akses kepustakaan kepada pengunjung, termasuk akses jurnal online yang dilanggan Kementerian Pendidikan Malaysia untuk perguruan tinggi. Tantangan dan dinamika perguruan tinggi, salah satunya dapat diatasi dengan kolaborasi (Wekke, 2019).

\section{Kerangka Konseptual}

Pelaksanaan Graduate Symposium merupakan bagian dari aktivitas perguruan tinggi untuk memperkaya pengalaman belajar mahasiswa. Praktik seperti ini sudah dilaksanakan di Inggris (Byram, \& Dervin, 2009), tidak hanya mahasiswa dan dosen, tetapi juga staf. Dengan adanya kegiatan seperti ini, akan membantu dalam peningkatan kemampuan (Sagaria, \& Johnsrud, 1988). Trend pelaksanaan program ini mulai meningkat, seiring dengan adanya tuntutan akreditasi dan juga keperluan antar lembaga (Verbik, \& Lasanowski, 2007). Pendidikan 
tinggi Islam tidak hanya memerlukan transformasi kelembagaan tetapi juga terkait dengan inovasi pembelajaran (Mujahidah, \& Wekke, 2019). Dengan demikian, prakarsa pelaksanaan Graduate Enhancement Program sebagai bagian dari Graduate Student Symposium in Southeast Asia yang dilaksanakan di tiga negara ini akan menjadi kesempatan bagi dosen dan mahasiswa untuk sama-sama belajar. Sementara bagi dosen akan menjadi peluang untuk mendiskusikan penelitian kolaboratif di tingkat regional, Asia Tenggara.

\section{Rancangan Jadwal}

Untuk skema jadwal kegiatan dapat dilihat dalam tabel 1 .

Tabel 1 Rancangan Jadwal Kegiatan

\begin{tabular}{|l|l|l|}
\hline Hari \& Tanggal & \multicolumn{1}{|c|}{ Kegiatan } & \multicolumn{1}{|c|}{ Keterangan } \\
\hline 18 September 2020 & Berangkat & \\
\hline 19 September 2020 & $\begin{array}{l}\text { University College of Yayasan } \\
\text { Pahang }\end{array}$ & $\begin{array}{l}\text { International Postgraduate Research } \\
\text { Conference }\end{array}$ \\
\hline 20 September 2020 & Workshop & $\begin{array}{l}\text { Selepas dhuhur terus ke Kuala } \\
\text { Terengganu }\end{array}$ \\
\hline & & Tidur di Scout-Inn. \\
\hline 21 September 2020 & Universiti Sultan Zainal Abidin & Malam: perbaikan tesis \\
\hline 22 September 2020 & & Graduate Student Colloquium \\
\hline 23 September 2020 & Fatoni University, Pattani & $\begin{array}{l}\text { Graduate Student Conference on } \\
\text { Innovation in Education }\end{array}$ \\
\hline 24 September 2020 & Pattani ke Kuala Lumpur & Sarapan di Prince of Songkla University \\
\hline & & Pattani ke Kuala Lumpur \\
\hline 25 September 2020 & $\begin{array}{l}\text { Kolej Universiti Islam } \\
\text { Selangor }\end{array}$ & Graduate Seminar on Islamic Studies \\
\hline & & malam ke Singapura by train \\
\hline 26 September 2020 & Singapura & $\begin{array}{l}\text { Workshop on Academic Writing at } \\
\text { Jamiyah Business College }\end{array}$ \\
\hline 27 September 2020 & Pulang & \\
\hline
\end{tabular}

\section{Simulasi Pembiayaan}

Untuk biaya program sepenuhnya tidak dikenakan pembiayaan. Peserta perlu membayar untuk biaya utama seperti transportasi baik untuk penerbangan atau transportasi lokal, penginapan, dan juga makan. Tidak ada biaya program yang dibayarkan kepada panitia. Setiap peserta memesan tersendiri tiket penerbangan sesuai dengan keinginan dan juga menyesuaikan kepada anggaran masing-masing. Demikian pula hotel dan penginapan untuk di Kuala Lumpur dan Singapura, dimana pilihan hotel tersedia. Sebagai gambaran dikemukakan dalam tabel 2. 
Tabel 2. Gambaran Biaya

\begin{tabular}{|l|l|l|}
\hline \multicolumn{1}{|c|}{ Komponen Biaya } & \multicolumn{1}{|c|}{ Kisaran Harga } & \multicolumn{1}{c|}{ Keterangan } \\
\hline Pesawat & Fluktuatif & $\begin{array}{l}\text { Pengecekan di website atau } \\
\text { aplikasi }\end{array}$ \\
\hline Transportasi & Malaysia RM 40-50/hari & Lokal \\
\hline & $\begin{array}{l}\text { Thailand menggunakan bis } \\
\text { sewaan }\end{array}$ & $\begin{array}{l}\text { Ditambah asuransi dan guide, } \\
\text { untuk disiapkan TBH 500- } \\
\text { 1000/orang }\end{array}$ \\
\hline Penginapan/Hotel & $\begin{array}{l}\text { Singapura menggunakan } \\
\text { transportasi umum }\end{array}$ & \\
\hline Komsumsi & Malaysia RM 120/kamar & \\
\hline & Malaysia RM 5-10/makan & \\
\hline & Thailand TBH 50-100/makan & \\
\hline & Singapura SGD 5-10/makan & \\
\hline
\end{tabular}

\section{Penutup}

Artikel ini merupakan gambaran sebagai maklumat awal dalam persiapan pelaksanaan kegiatan Graduate Symposium. Untuk detail dan kelengkapan lainnya, akan dibuat sebagai informasi tambahan. Juga penyusunan jadwal, akan dilakukan penyesuaian terkait dengan kesediaan tuan rumah untuk mengadakan acara bersama.

Setiap lembaga atau perguruan tinggi yang mengikutkan dosen atau mahasiswanya, sepanjang memberikan izin untuk pencantuman logo, akan ditempatkan dalam media sosialisasi dan juga ketika pelaksanaan kegiatan berlangsung. Urutan logo tidak didasarkan pada sebuah kriteria, hanya ditempatkan secara random.

\section{Daftar Pustaka}

Byram, M., \& Dervin, F. (Eds.). (2009). Students, staff and academic mobility in higher education. Cambridge Scholars Publishing.

Mujahidah, M., \& Wekke, I. S. (2019). Transformasi Perguruan Tinggi Keagamaan Islam Indonesia. https://doi.org/10.31227/osf.io/46evm.

Rajafi, A. (2018). Khazanah Islam, Perjumpaan Kajian dengan Ilmu Sosial. Yogyakarta: Deepublish.

Sagaria, M. A. D., \& Johnsrud, L. K. (1988). Mobility within the Student Affairs Profession: Career Advancement through Position Change. Journal of College Student Development, 29(1), 30-40.

Verbik, L., \& Lasanowski, V. (2007). International student mobility: Patterns and trends. World Education News and Reviews, 20(10), 1-16.

Wekke, I. S. (2019). Dinamika Perguruan Tinggi Islam dan Tantangan Masa Depan. https://doi.org/10.31227/osf.io/hyqtr.

Wekke, I. S., Kahar, M. S., \& Amri, I. (2018). Perguruan Tinggi Tanah Papua dan Strategi Pengembangan Pendidikan Tinggi. https://doi.org/10.31227/osf.io/m3kvb. 